\title{
PENGARUH POLUTAN TERHADAP STRUKTUR MORFOLOGI STOMATA DAUN TREMBESI (Samanea saman (Jacg) Merr)
}

\section{Effect of Pollutants on Morphology of Stomata Leaves of Trembesi (Samanea saman (Jacg) Merr)}

\author{
Pratiwi Dyah Kusumo dan Manogari Sianturi \\ Fakultas Kedokteran UKI, Jakarta, Indonesia \\ email: pratiwi.kusuma@uki.ac.id
}

\begin{abstract}
Trembesi (Samanea saman) is one of the plants that is currently developed as one of the green line plants. Stomata as part of the leaf that has the ability to bind air, especially oxygen and carbon dioxide, is one part of the plant that can be used as an indicator to see the effect of pollutants contained in the air. The result was obtained by using an electron microscope to analyze the morphological structure of stomata leaves Trembesi (Samanea saman). Location was determined by two groups, the control group was at the UKI campus environment which was away from air pollution and the treatment group was in the Cawang police station where many vehicles passed through. Within a 90 days after treatment of pollutant exposure to plants, the structure of Trembesi leaf stomata was observed using an electron microscope. Based on the observation, the leaf position in the middle of the tree and the position of the leaf at the bottom of the tree, it was found that the leaves placed in the control position had a finer stomata mouth structure, more leaf hairs, and a wider diameter. While on the leaves that are placed on the location exposed to pollutants, has an irregular leaf mouth structure, fewer leaf feathers, and smaller diameter. This study can be concluded that there was an effect of exposure of pollutant that could change morphology of stomata leaves of Trembesi (Samanea saman).
\end{abstract}

Keywords: Samanea saman (Jacq) Merr, stomata, pollutant. 


\section{PENDAHULUAN}

Salah satu permasalahan lingkungan global saat ini yang menjadi isu penting adalah pemanasan global. Pemanasan global merupakan akibat dari penyerapan gelombang panas oleh gas-gas atmosfer sehingga suhu atmosfer bumi naik yang disebut sebagai Efek Rumah Kaca (EFK). Gas-gas atmosfer yang dapat menyerap gelombang panas adalah Gas Rumah Kaca (GRK). Gas rumah kaca yang penting adalah karbondioksida $\left(\mathrm{CO}_{2}\right)$. Karbondioksida dihasilkan dari pernafasan, pembusukan, dan pembakaran. Menurut Dewan Nasional Perubahan Iklim (DNPI 2010) emisi gas karbokdioksida yang dihasilkan transportasi memang tidak banyak namun berkembang dengan pesat. Tanaman mempunyai kemampuan untuk berfotosintesis yang menggunakan karbondioksida dan air sebagai bahan baku (Purwaningsih, 2007; Haska, 2011).

Salah satu antisipasi yang dapat dilakukan dalam menghadapi perubahan iklim dan pemanasan global diakibatkan oleh meningkatnya gas rumah kaca adalah mengetahui jenis-jenis tanaman hutan kota yang mempunyai kemampuan tinggi dalam menyerap $\mathrm{CO}_{2}$. Efek gas rumah kaca dapat diminimalisasi, oleh karenanya perlu dilakukan upaya pendekatan dalam usaha untuk mengetahui kemampuan serapan $\mathrm{CO}_{2}$ oleh tanaman hutan kota (Purwaningsih, 2007). Untuk mengurangi semakin tingginya bahan pencemar yang dihasilkan kendaraan bermotor, perlu adanya pohon-pohon yang berfungsi sebagai penyerap dan penjerap bahan pencemar dan debu di udara yang dihasilkan kendaraan bermotor. Pohon sering disebut-sebut sebagai paru-paru kota. Sejumlah pohon berdaun lebar diyakini dapat menjerap bahanbahan pencemar udara. Sel-sel daun berfungsi menangkap karbondioksida dan timbal untuk kemudian diolah dalam sistem fotosintesis. Proses fotosintesis mampu mengubah karbondioksida $\left(\mathrm{CO}_{2}\right)$ yang dikeluarkan dari sistem pernapasan menjadi oksigen yang dibutuhkan paru-paru (Martuti, 2013). Serapan polutan melalui stomata Pohon Trembesi yang diketahui memiliki peran sebagai pohon peneduh, merupakan kajian yang akan diteliti untuk membuktikan pengaruh polutan terhadap perubahan struktur morfologi Daun Trembesi. 
Udara merupakan campuran dari gas yang terdapat pada permukaan bumi, yang terdiri dari sekitar $78 \%$ Nitrogen, $20 \%$ Oksigen, 0,93 \% Argon, 0,03 \% Karbon Dioksida $\left(\mathrm{CO}_{2}\right)$ dan udara dikatakan "Normal" dan dapat mendukung kehidupan manusia apabila komposisinya seperti tersebut diatas. Udara dimana di dalamnya terkandung sejumlah oksigen, merupakan komponen esensial bagi kehidupan, baik manusia maupun makhluk hidup lainnya. Disisi lain, apabila terjadi penambahan gas-gas lain yang menimbulkan gangguan serta perubahan komposisi tersebut, maka dikatakan udara sudah tercemar/terpolusi. Pencemaran udara diartikan sebagai adanya bahan atau zat-zat asing di udara dalam jumlah yang dapat menyebabkan perubahan komposisi atmosfer normal (Santoso, 2012).

\section{METODE PENELITIAN}

Pohon Trembesi didapatkan dari Pohon Budidaya Trembesi, Bumi Serpong Damai, Tangerang. Pohon Trembesi yang memiliki tinggi sekitar satu meter dengan kisaran usia 4 bulan, dibiakkan dan dipindahkan pada media tanah yang lebih baik. Setelah siap untuk ditempatkan pada lokasi pengamatan, maka Pohon Trembesi dipindahkan pada tiga lokasi pengamatan:

1. Lokasi Kontrol yang relatif bebas dari polutan, berada dalam lingkungan kampus Universitas Kristen Indonesia

2. Lokasi Polutan (1) dekat dengan jalan di persimpangan cawang bawah, pintu keluar tol Halim

3. Lokasi Polutan (2) dekat pos polisi cawang bawah, relatif sedikit terlindungi pohon besar lainnya.

Setelah masa pengamatan selama 90 hari, maka Pohon Trembesi berikut dengan pot nya dipindahkan ke Puslabfor POLRI untuk dilakukan pengamatan dengan memakai mikroskop elektron SEM EDX. Adapun pengamatan dibedakan berdasarkan:

a. Lokasi pengamatan: Kontrol, Dekat Jalan Pintu keluar tol, Dekat Pos Polisi

b. Tingkat posisi daun: Daun yang berada di posisi tengah (kira-kira 1/3 dari bagian pucuk pohon) dan daun yang ada di bagian bawah pohon (kira-kira 2/3 dari bagian pucuk pohon). 
c. Permukaan daun: permukaan bawah dan permukaan atas.

Gambaran morfologi yang diamati adalah bentuk umum stomata, lebar dan panjang stomata, gambaran bulu di sekitar permukaan daun. Dalam hal ini tidak dilakukan analisis statistik karena hanya merupakan pengamatan deskriptif.

\section{HASIL}

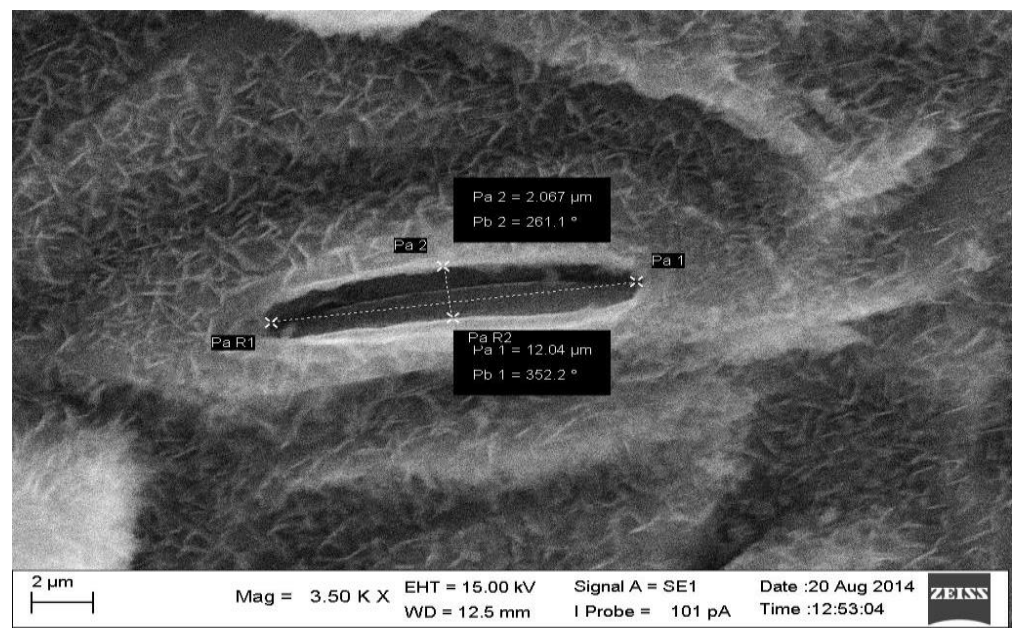

Gambar 1. Daun bagian tingkat bawah di lokasi kontrol (permukaan bagian bawah daun)

Morfologi daun bagian tingkat bawah di lokasi kontrol (permukaan bagian bawah daun), permukaan mulut stomata tidak berlekuk, nampak tidak banyak kerusakan struktur daun, bulu nya nampak jelas dan panjang. Diameter 2,067 $\mu \mathrm{m}$ dan panjang 12,04 $\mu \mathrm{m}$. 
Kusumo, D. K. dan Sianturi, M.

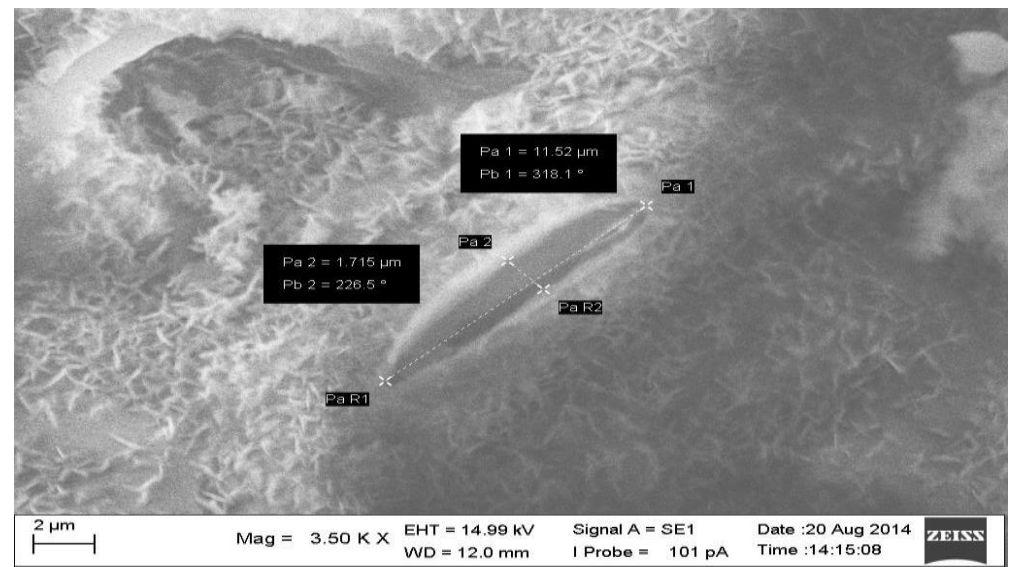

Gambar 2. Daun tingkat bagian bawah, lokasi dekat jalan (permukaan bagian bawah daun)

Morfologi daun bagian tingkat bawah di lokasi dekat jalan permukaan bagian bawah daun, permukaan mulut stomata tidak berlekuk, nampak tidak banyak kerusakan struktur daun, bulu nya nampak jelas dan panjang, namun kerapatannya berkurang. Diameter $1,715 \mu \mathrm{m}$ dan panjang $11,62 \mu \mathrm{m}$.

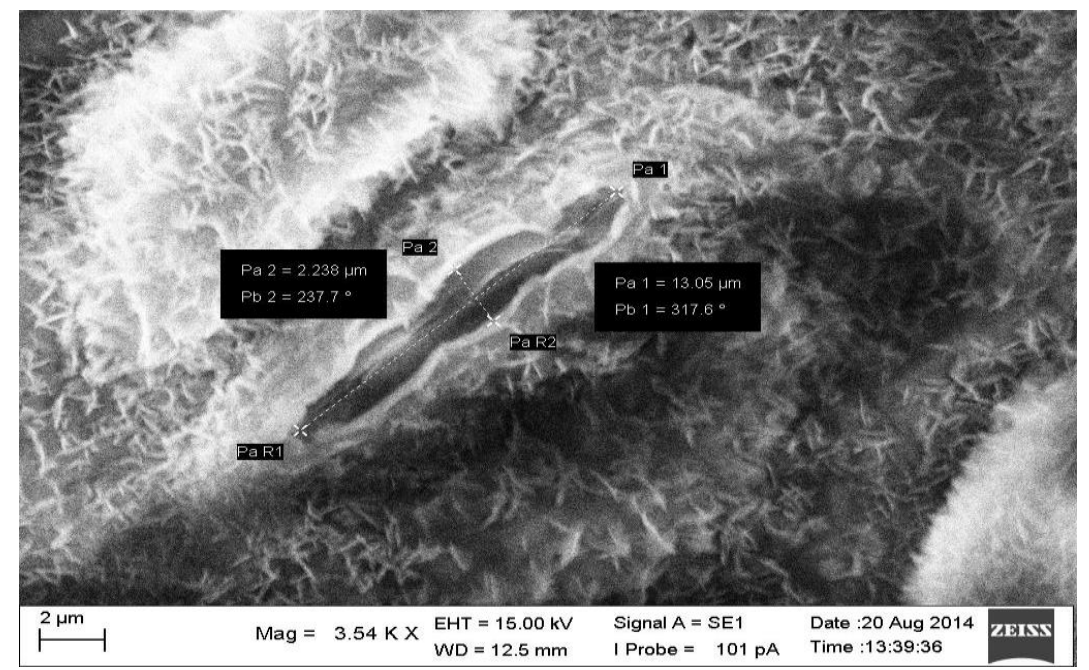

Gambar 3. Daun tingkat bawah, lokasi dekat pos polisi (permukaan bagian bawah daun)

Morfologi daun bagian tingkat bawah di lokasi pos polisi permukaan bagian bawah daun, permukaan mulut stomata 
berlekuk, nampak banyak kerusakan struktur daun, bulu nya nampak jelas dan panjang, namun kerapatannya tidak beraturan. Diameter 2,238 $\mu \mathrm{m}$ dan panjang 13,05 $\mu \mathrm{m}$.

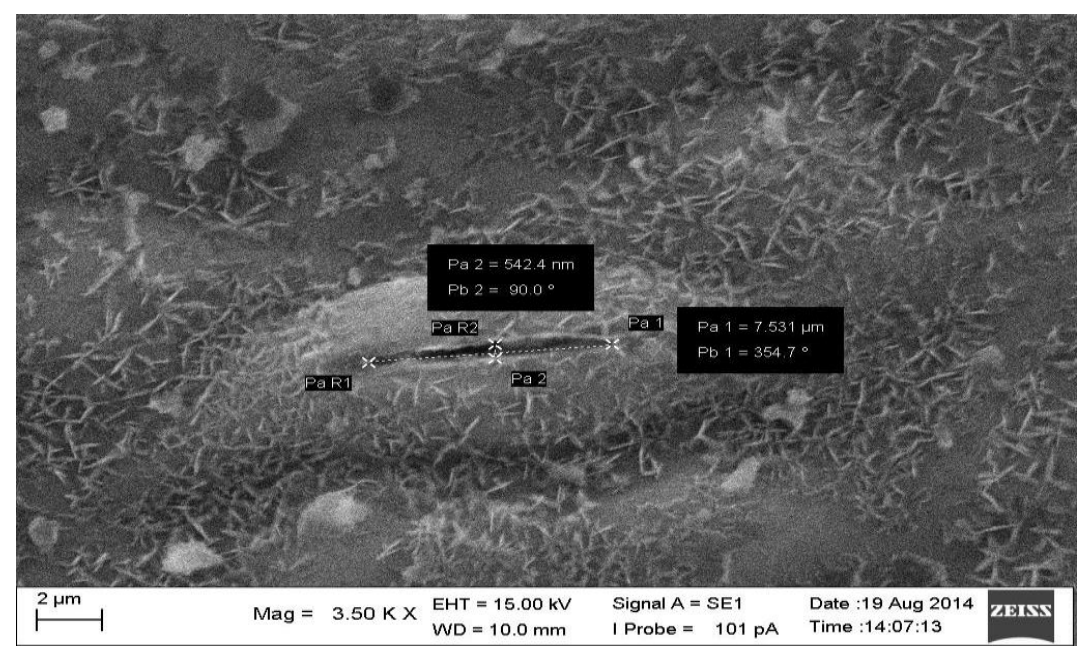

Gambar 4. Daun tingkat tengah, lokasi kontrol (permukaan bagian bawah)

Morfologi daun bagian tingkat tengah di lokasi kontrol permukaan bagian bawah daun, permukaan mulut stomata tidak banyak lekukan, sel penjaga strukturnya jelas, nampak beberapa partikulat yang menempel, bulu nya nampak jelas dan panjang, namun kerapatannya jarang. Diameter 542,4 $\mathrm{nm}$ dan panjang 7,531 $\mu \mathrm{m}$.

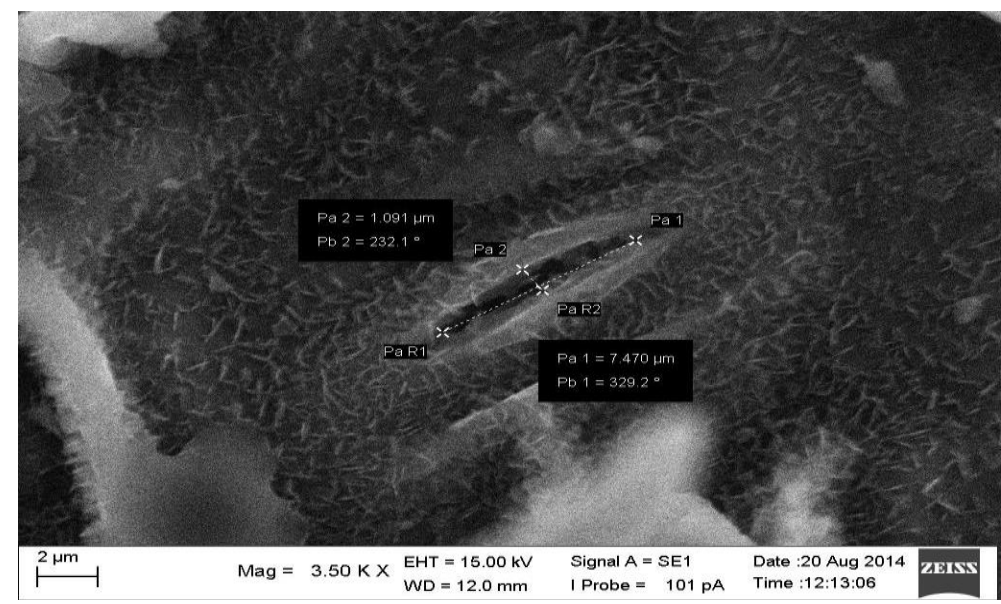

Gambar 5. Daun tingkat tengah, lokasi dekat jalan (bagian bawah daun) 
Morfologi daun bagian tingkat tengah di lokasi dekat jalan permukaan bagian bawah daun, permukaan mulut stomata tidak banyak lekukan, sel penjaga strukturnya kurang jelas, nampak beberapa partikulat yang menempel, bulu nya nampak jelas namun tidak terlalu panjang, kerapatannya jarang. Diameter $1,091 \mu \mathrm{m}$ dan panjang 7,470 $\mu \mathrm{m}$.

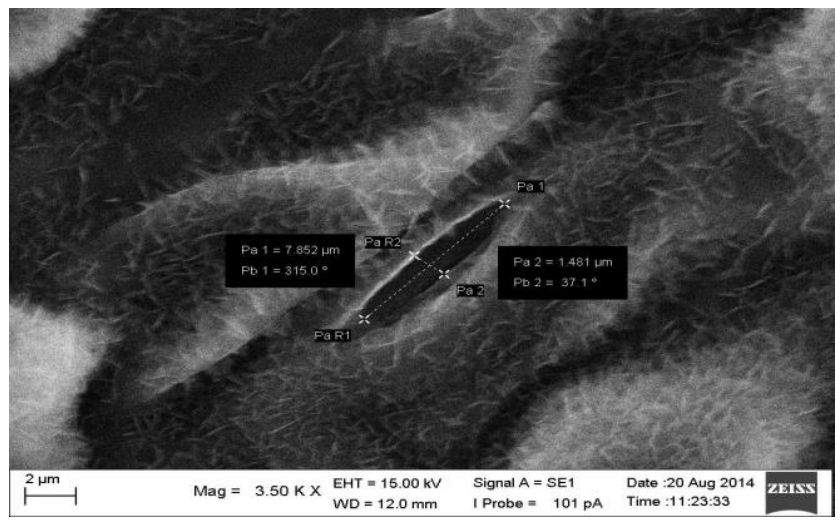

Gambar 6. Daun tingkat tengah, lokasi dekat pos polisi (permukaan bagian bawah daun)

Morfologi daun bagian tingkat tengah di lokasi dekat pos polisi permukaan bagian bawah daun, permukaan mulut stomata tidak banyak lekukan, sel penjaga strukturnya kurang jelas, tidak partikulat yang menempel, bulu nya nampak jelas dan panjang, namun kerapatannya cukup tinggi. Diameter $1,481 \mu \mathrm{m}$ dan panjang $7,852 \mu \mathrm{m}$.

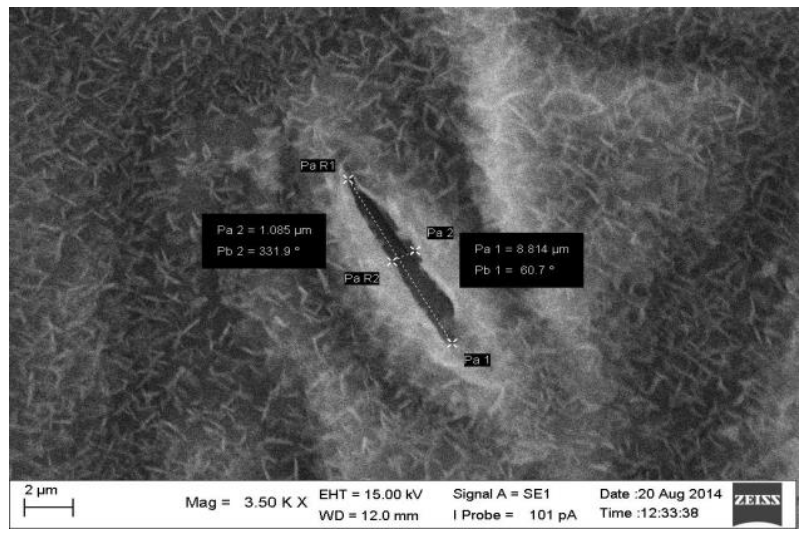

Gambar 7. Daun tingkat bawah, lokasi kontrol (permukaan bagian permukaan atas daun) 
Morfologi daun bagian tingkat bawah di lokasi kontrol permukaan bagian atas daun, permukaan mulut stomata tidak banyak lekukan, sel penjaga strukturnya nampak jelas, tidak ada partikulat yang menempel, bulu nya nampak jelas dan panjang, namun kerapatannya cukup tinggi. Diameter $1,085 \mu \mathrm{m}$ dan panjang $8,814 \mu \mathrm{m}$.

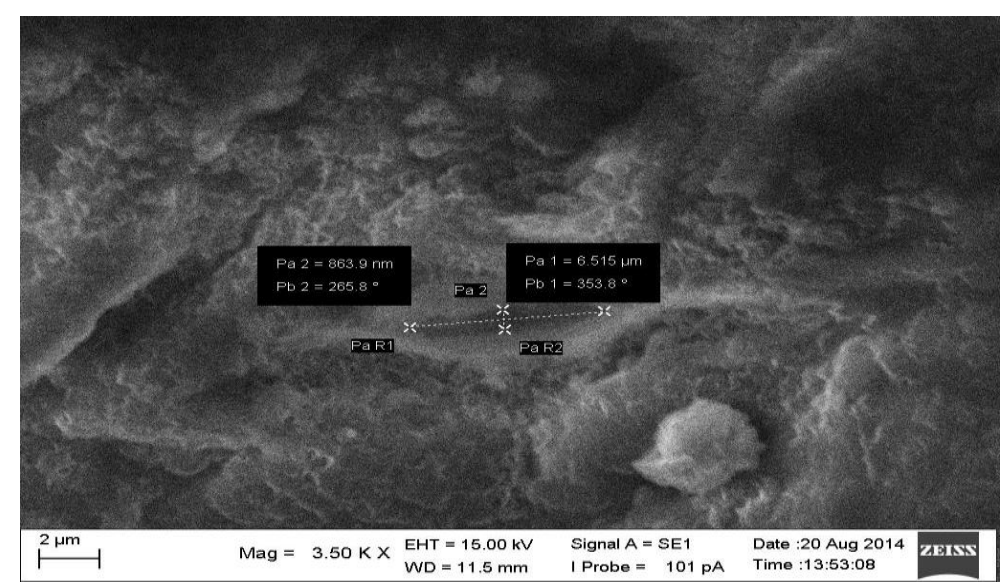

Gambar 8. Daun tingkat bawah, lokasi dekat jalan (permukaan bagian permukaan atas daun)

Morfologi daun bagian tingkat bawah di lokasi dekat jalan permukaan bagian atas daun, permukaan mulut stomata tidak jelas (tertutup), sel penjaga strukturnya tidak jelas, tidak partikulat yang menempel, bulu nya nampak tidak jelas. Diameter 863,9 nm dan panjang $6,515 \mu \mathrm{m}$. 


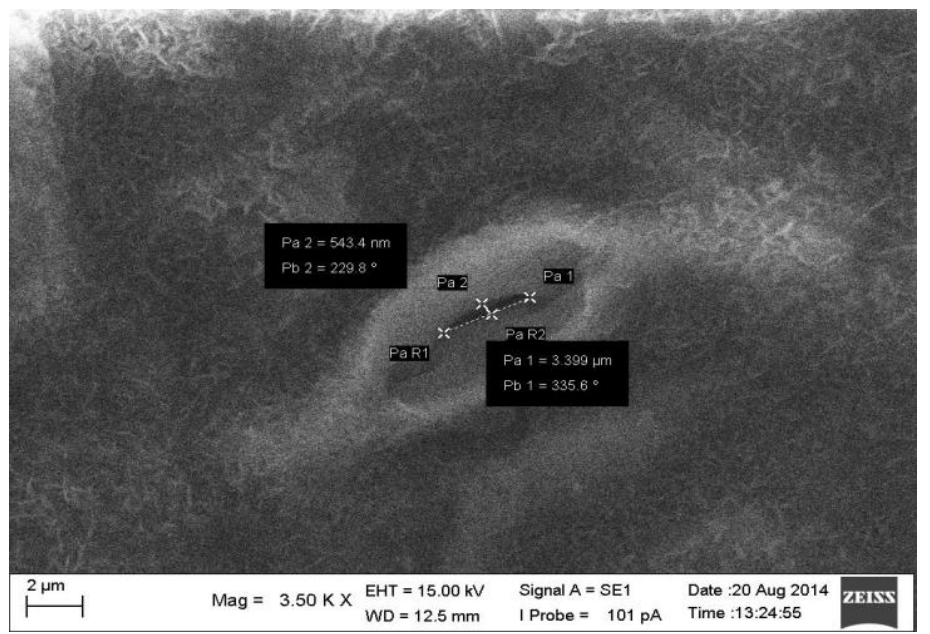

Gambar 9. Daun tingkat bawah, lokasi dekat pos polisi (permukaan bagian permukaan atas daun

Morfologi daun bagian tingkat bawah di lokasi dekat pos polisi permukaan bagian atas daun, permukaan mulut stomata jelas, sel penjaga strukturnya kurang jelas, tidak ada partikulat yang menempel, bulu nya nampak tidak jelas. Diameter $543,4 \mathrm{~nm}$ dan panjang 3,399 $\mu \mathrm{m}$.

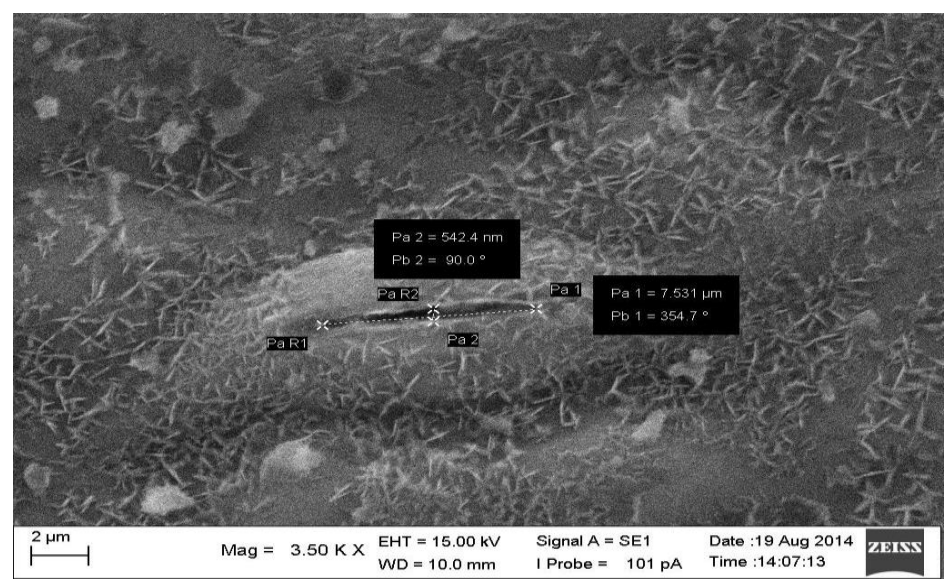

Gambar 10. Daun tingkat tengah, lokasi kontrol (permukaan bagian atas daun)

Morfologi daun bagian tingkat tengah di lokasi kontrol permukaan bagian atas daun, permukaan mulut stomata tidak banyak lekukan, sel penjaga strukturnya nampak jelas, tidak ada partikulat yang menempel, bulu nya nampak jelas dan panjang, 
namun kerapatannya jarang. Diameter 542,4 $\mathrm{nm}$ dan panjang $7,531 \mu \mathrm{m}$.

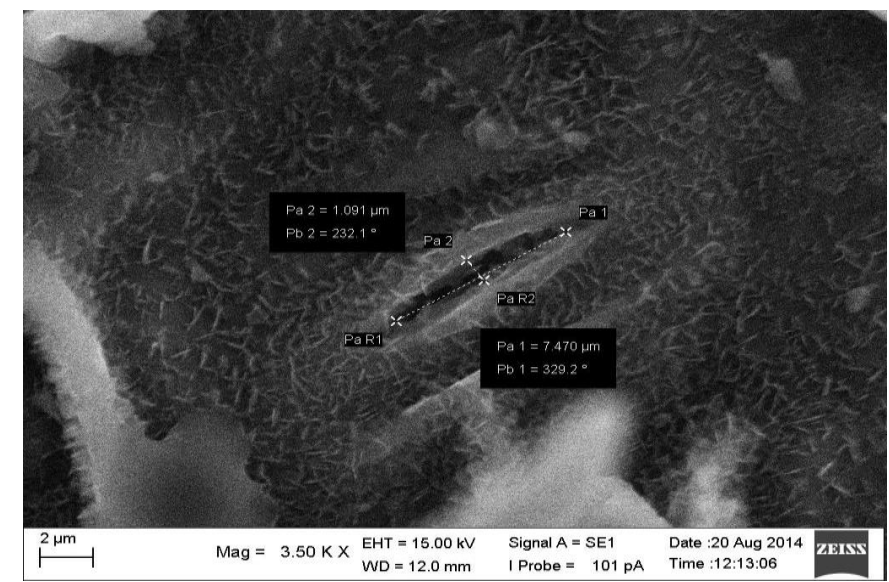

Gambar 11. Daun tingkat tengah, lokasi dekat jalan (permukaan daun bagian atas)

Morfologi daun bagian tingkat tengah di lokasi dekat jalan permukaan bagian atas daun, permukaan mulut stomata tidak banyak lekukan, sel penjaga strukturnya tidak begitu jelas, sedikit partikulat yang menempel, bulu nya nampak jelas dan panjang, namun kerapatannya tidak terlalu tinggi. Diameter $1,091 \mu \mathrm{m}$ dan panjang 7,470 $\mu \mathrm{m}$.

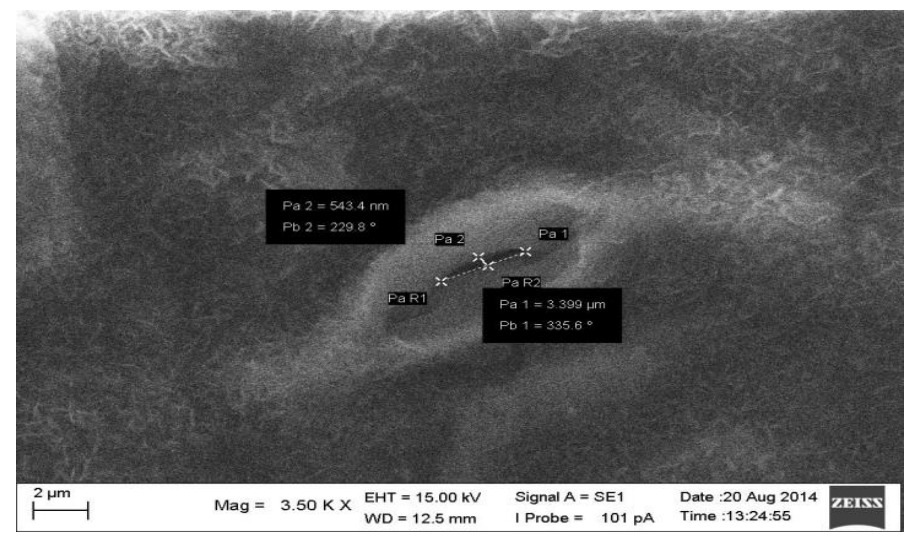

Gambar 12. Daun tingkat tengah, lokasi pos polisi (permukaan daun bagian atas) 
Morfologi daun bagian tingkat tengah di lokasi dekat pos polisi permukaan bagian atas daun, permukaan mulut stomata tidak banyak lekukan, sel penjaga strukturnya tidak jelas, tidak ada partikulat yang menempel, bulu nya nampak kurang jelas, namun kerapatannya cukup tinggi. Diameter 543,4 nm dan panjang 3,399 $\mu \mathrm{m}$.

\section{PEMBAHASAN}

Pencemaran udara semakin hari semakin memprihatinkan. Terutama dikota-kota besar yang banyak terdapat pengguna kendaraan bermotor. kendaraan bermotor menyumbang 85\% pencemaran udara yang mengandung timah hitam/timbal $(\mathrm{Pb})$, suspended particulate matter (spm), oksida nitrogen (NOx), oksida sulfur $\left(\mathrm{SO}_{2}\right)$, hidrokarbon ( $\left.\mathrm{HC}\right)$, karbonmonoksida $\left(\mathrm{CO}_{2}\right)$, oksida fotokimia (Ox). Meningkatnya jumlah kendaraan bermotor di indonesia, akan meningkatkan pencemaran udara. Kandungan timah hitam di sekitar jalan raya atau kawasan perkotaan sangat tergantung pada kecepatan lalu lintas, jarak terhadap jalan raya, arah dan kecepatan angin, cara mengendarai dan kecepatan kendaraan. Bioakumulasi timah hitam terhadap daun pada tanaman akan lebih banyak terjadi pada tanaman yang tumbuh di pinggir jalan besar yang padat kendaraan bermotor (Manik, 2015).

Berdasarkan hasil pengamatan struktur morfologi daun Pohon Trembesi, maka kita dapat melihat secara keseluruhan bahwa ada sedikit pengaruh lokasi posisi daun pada pohon trembesi, dimana daun yang berada pada posisi bawah memiliki struktur stomata yang lebih sedikit bulu dan bentuk mulut stomata yang tidak beraturan. Beberapa juga nampak ditemukan adanya gambaran bercak yang diasumsikan sebagai polutan. Kerapatan bulu di daun bagian bawah juga berkurang, struktur berlekuk, bila dibandingkan dengan posisi daun yang berada pada tingkat tengah. Hasil pengamatan ini sejalan dengan penelitian yang dilakukan Manik, dimana terdapat korelasi yang kuat antara jumlah $\mathrm{Pb}$ dengan kepadatan lalulintas dan jumlah $\mathrm{Pb}$ dengan jumlah stomata. Partikel $\mathrm{Pb}$ sebagai salah satu polutan di udara jatuh dan mengendap pada permukaan daun. Penyerapan $\mathrm{Pb}$ pada daun terjadi karena partikel $\mathrm{Pb}$ di udara masuk ke dalam daun melalui 
proses penyerapan pasif. Masuknya partikel $\mathrm{Pb}$ ke dalam jaringan daun sangat dipengaruhi oleh ukuran dan jumlah dari stomata. Semakin besar ukuran dan semakin banyak jumlah stomatanya maka semakin besar pula penyerapan $\mathrm{Pb}$ masuk ke dalam daun. Demikian pula halnya dengan posisi penempatan pohon di jalan raya berkorelasi dengan dampak pada struktur daun Trembesi (Manik, 2015).

Tanaman angsana (Pterocarpus indicus Willd), akasia (Acacia mangium), dan trembesi (Samanea saman) merupakan jenis tanaman yang banyak digunakan di Kota Batam sebagai peneduh jalan. Jenis tanaman ini memiliki akar yang dapat bertahan terhadap kerusakan yang disebabkan oleh getaran kendaraan, mudah tumbuh di daerah panas, dan tahan terhadap angin. Sulasmini menyatakan bahwa tanaman peneduh jalan dapat menyerap unsur kimia pencemar yang berasal dari asap kendaraan bermotor dan industri. Tiga jenis tanaman ini merupakan tanaman pohon dengan ukuran pohon yang tinggi. Memiliki morfologi daun yang berbeda. Angsana dan akasia permukaan daunnya licin sedangkan trembesi permukaan daunnya agak kasar. Tanaman ini mampu menyerap logam berat melalui daun, kulit pohon, cabang, ranting dan akarnya. Kemampuan tanaman menjerap dan menyerap logam berat berbeda-beda menurut jenis tanamannya. Secara teoritis permukaan daun yang berbulu dan berlekuk mempunyai kemampuan lebih tinggi dibanding daun yang halus dan licin. Semua tanaman memiliki kelebihan dan kekurangan yang saling melengkapi dalam menyerap logam berat (Nilawati, 2011).

Daun Trembesi memiliki struktur daun yang berbulu, kasar terutama pada permukaan daun bagian bawah. Struktur yang demikian memungkinkan daun trembesi mampu mengikat polutan dan menyerapnya melalui stomata. Penelitian yang bersifat deskriptif ini tidak dapat memberikan gambaran yang sangat detail tentang morfologi struktur stomata karena bersifat sampling, Namun secara umum dapat diperoleh gambaran bahwa struktur stomata daun Trembesi yang diberi perlakuan lokasi dekat dengan sumber polutan memiliki ukuran diameter dan panjang stomata yang lebih kecil dibandingkan dengan lokasi kontrol. Hal ini diasumsikan bahwa stomata beradaptasi dengan paparan polutan dengan reaksi sel penjaga yang ada di sekitar stomata. Daun 
Trembesi memiliki permukaan daun kecil, halus dan tidak berbulu. Hal ini memungkinkan, pengikatan polutan tidak akan sekuat jenis daun yang lebih tebal dan besar.

Partikel logam berat yang menempel pada permukaan daun yang morfologinya berbeda akan menyebabkan konsentrasinya berbeda pula. Partikel logam berat yang menempel pada permukaan daun yang lebih lebar dan lebih kasar akan memberi akumulasi tujuh kali lebih besar dari pada permukaan daun yang licin. Kemampuan daun menyerap partikel sangat dipengaruhi oleh keadaan permukaan daun yaitu kebasahan, kelengketan, dan bulu daun. Penyerapan bahan polutan melalui daun terjadi karena partikel timbal diudara jatuh dan mengendap pada permukaan daun. Permukaan daun yang lebih kasar, berbulu dan lebar akan lebih mudah menangkap partikel daripada permukaan daun yang halus, tidak berbulu dan berukuran sempit (Suhadiyah, 2010). Demikian pula hal nya dengan panjang dan diameter daun stomata. Pengamatan rata-rata diameter daun Trembesi adalah 1,332 $\mu \mathrm{m}$, sedangkan diameternya rata rata adalah $1,564 \mu \mathrm{m}$, rerata panjang 8,017 $\mu \mathrm{m}$. Hasil pengamatan dibandingkan dengan hasil pengamatan Mutadhiroh pada Tahun 2015, dengan menggunakan diameter batang pohon $15 \mathrm{~cm}$, rentang diameter tajuk daun pohon 3 meter. Pengamatan Mutadhiroh rerata diameter 3,4-4 $\mu$ m dan rerata panjang 15-16 $\mu \mathrm{m}$. Dengan demikian hasil penelitian yang dilakukan sejalan dengan hasil pengamatan Mutadhiroh (Mutadhiroh, 2015).

\section{KESIMPULAN}

Perlakuan paparan polutan dari lingkungan terpolusi di sekitar daerah Cawang Jakarta, memberikan pengaruh perubahan struktur morfologi stomata secara umum (mulut stomata, kerapatan bulu, diameter dan panjang stomata). Walaupun bersifat deskriptif, gambaran umum memperlihatkan struktur stomata serta kerapatan dan bentuk bulu daun nampak lebih jelas pada daerah kontrol dibandingkan daerah polutan. 


\section{DAFTAR PUSTAKA}

Purwaningsih, S. (2007). Kemampuan serapan karbondioksida pada tanaman hutan kota di Kebun Raya Bogor. Skripsi. Departemen Konservasi Sumberdaya Hutan dan Ekowisata. Fakultas Kehutanan. Institut Pertanian Bogor. https://repository. ipb.ac.id/handle/123456789/32959 diakses pada 16 Juni 2016.

Haska, H.P., D. P, Lestari, R. Fitria. (2011). Pohon Trembesi sebagai alternatif terbaik untuk mensukseskan target penurunan emisi karbon. Program Kreativitas Mahasiswa. Intitut Pertanian Bogor. Diakses melalui https://www.google.com/ pada 17 Juni 2016

Martuti, N.K.T. (2013). Peranan tanaman terhadap pencemaran udara di jalan protocol Kota Semarang. Biosaintifika berkala ilmiah biologi. (5): 1

Santoso, S.N. (2012). Penggunaan tumbuhan sebagai pereduksi pencemaran udara. Jurusan Teknik Lingkungan-FTSP-ITS. Diakses melalui: digilib.its.ac.id/public/ITS-Undergraduate16616-Abstract_id-pdf.pdf pada 17 Juni 2016

Damayanti, F. (2007). Analisis jumlah kromosom dan anatomi stomata pada beberapa plasma nutfah pisang (Musa sp.) asal Kalimantan Timur. Bioscientiae. (4): 2: 53-61

Dahlan, E. N., (1989). Studi Kemampuan Tanaman Dalam Menjerap dan Menyerap Timbal Emisi dari Kendaraan Bermotor. Tesis, Pasca Sarjana. Institut Pertanian Bogor. Bogor. Diakses melalui pada scholar.google.co.id/citations?user=4nAGJrkAAAAJ\&hl =id pada 20 Juni 2016

Manik, S.T., Prihanta, W., Purwanti, E. (2015). Analisis Kandungan Timbal (Pb) pada Daun Tamarindus indica dan Samanea saman di Kecamatan Garum Kabupaten Blitar. Seminar Nasional XII Pendidikan Biologi FKIP UNS 2015. Diakses melalui https://media.neliti.com/media/publications/173966-IDnone.pdf pada 23 Desember 32017 
Nilawati. (2011). Analisis logam berat $\mathrm{Pb}, \mathrm{Zn}$, dan Cr pada tiga jelis tanaman peneduh pinggir jalan di Kota Batam kepulauan Riau. Thesis. Sekolah Pascasarjana. Institut Pertanian Bogor. Diakses melalui https:// portalgaruda.org/article.php? pada 23 Desember 2017.

Suhadiyah, S., Umar, M.R., Surni. Studi banding akumulasi Timbal (Pb) pada daun Hibiscus tiliaceus L. dan daun ki hujan Samanea Saman (Jacq.) Merr. di Makassar. Seminar Nasional HUT Kebun Raya Cibodas Ke-159 ISBN 978-979-99448-6-3 diakses melalui https:// krbogor.lipi.go.id/en/publikasi/download/ 144

Mutadhiroh, C. Karakteristik anatomi dan potensi daun trembesi (Albizia saman (Jaqq) Merr.) di ruas jalan Kota Malang sebagai akumulator logam berat timbal (Pb). Skripsi. Jurusan Biologi. Fakultas Sains dan Tekhnologi. Universitas Islam Indonesia (UIN) Maulana Malik Ibrahim. Diakses melaui: http://etheses.uin-malang.ac.id/2984/1/10620074.pdf pada 23 Desember 2017. 